\title{
Çocuklarda Akut Apandisit; Ultrasonografinin Tanısal Güvenilirliğinin Değerlendirilmesi
}

\section{Acute Appendicitis in Children; Assessment of Diagnostic Reliability of Ultrasonography}

\author{
Hasan Özkan GEZER ${ }^{1}$, Abdülkerim TEMiZ ${ }^{1}$ Semire EZER ${ }^{1}$, Emine INCE$^{1}$, Şenay DEMiR², \\ Bermal HASBAY ${ }^{3}$
}

\begin{abstract}
'Başkent Üniversitesi Tıp Fakültesi, Çocuk Cerrahisi Anabilim Dalı, Adana, Türkiye
'Bașkent Üniversitesi Tıp Fakültesi, Radyoloji Anabilim Dalı, Adana, Türkiye

${ }^{3}$ Bașkent Üniversitesi Tıp Fakültesi, Tıbbi Patoloji Anabilim Dalı, Adana, Türkiye
\end{abstract}

\section{Öz}

Amaç: Akut apandisit pediatrik yaş grubunda zamanında teșhis edilmez ise perforasyon gibi önemli komplikasyonlar ile morbid seyredebilecek abdominal acillerin başında yer alır. Olgularının çoğunda doğru tanı konabilir. Ancak endişeli, huzursuz ve ağrısı olan bir çocukta semptomların seyrini saptamak oldukça zordur. Ayrıca, henüz iletişim becerileri iyi gelişmemiş küçük bir çocuğun yakınmalarını iyi ifade edemeyeceği de göz önüne alındığında, çocuklarda tanıyı koymak erișkinlere kıyasla daha zordur. Bu çalıșmanın amacı pediatrik hastalarda akut apandisit tanısında abdominal ultrasonografinin (USG) etkinliğini değerlendirmektir.

Gereç ve Yöntemler: 2012-2019 yılları arasında çocuk cerrahisi kliniğinde apandisit tanısı ile ameliyat edilen, 1-18 yaş arası ve ameliyattan önce USG yapılmış hastalar çalışmaya dahil edildi. Demografik göstergeler, tanı anındaki USG bulguları, ameliyat verileri ve patoloji raporları geriye dönük olarak değerlendirildi.

Bulgular: Ikiyüzüç (\% 40) kız, 297 (\% 60) erkek olmak üzere toplam 500 hasta değerlendirildi. Hastaların ortalama yaşı $10.1 \pm 3.9$ ylldı. Ameliyat öncesi USG verilerine göre; hastaların \% 30'u normal, \%70'i akut apandisit (bunlardan \% 10'u perfore) șeklinde rapor edildi. Patolojik tanı açııından bakıldığında ise ameliyat edilen hastaların \% 8'inde normal apendiks dokusu (negatif apendektomi) tespit edilmiş̦ti. Çalışmamızda USG' nin duyarlılı̆ı \% 71.96, özgüllügü \% 48.78 ve doğruluğu \% 70.06 olarak tespit edildi. Pozitif ve negatif prediktif değerler ise sırasıyla \% 94.03 ve \% 13.42 olarak bulundu.

Sonuç: Elde edilen sonuçlara göre, çocuklarda akut apandisit tanısında USG, ucuz ve kolay uygulanabilen ancak güvenilirliği hala tartışmalara yol açabilecek bir test olarak değerlendirildi. USG'nin apandisit lehine raporlandığı hastalarda apandisit aleyhine raporlanmış olanlara göre tanı doğruluğunun daha yüksek olduğu bulundu. Ultrasonografik değerlendirmenin apandisit ile uyumlu olmadığı hastaların ise klinik bulgularının daha dikkatlice tekrar gözden geçirilmesi ve gerekirse ileri tetkik yapılması gerektiğini düşünüyoruz.

Anahtar Sözcükler: Apandisit, Çocuklar, Duyarlllik, Özgünlük, Ultrasonografi

\section{(1)}

GEZER HÖ : :0000-0002-4635-2613 TEMIZ A : :0000-0001-8789-6003 EZER S : :0000-0002-9597-3264 INCE E : :0000-0002-2120-1958 DEMIR Ş : :0000-0002-4209-9075 HASBAY B : :0000-0002-7941-7962

\begin{abstract}
Çıkar Çatışması / Conflict of Interest: Tüm yazarlar adına, sorumlu yazar çıkar çatışması olmadığını belirtir.
Etik Kurul Onayı / Ethics Committee Approval: Bu çalışmada ulusal ve uluslararası etik kurallara uyulmuştur. Çalışma için Başkent Üniversitesi, Tıp ve Sağllik Bilimleri Araştırma Kurulu'ndan 14.01.2019 tarih ve KA20/12 nolu onay alınmıştır.

Yazarların katkısı / Contribution of the Authors: GEZER HÖ: Araștırma ve/veya makalenin hipotezini veya fikrini olușturan, Sonuçlara ulașmak için planlama/ metodoloji belirleme, Araștırma/çalıșmanın sorumluluğunu üstlenmek, ilerlemenin seyrini denetlemek, Hasta takibinde sorumluluk almak, ilgili biyolojik malzemelerin toplanması, veri yönetimi ve raporlama, deneylerin yürütülmesi, Sonuçların mantıksal olarak Yorumlanması ve sonuçlandırıması, Çalışma için gerekli literatür taramasında sorumluluk almak, Çalışmanın bütününün veya önemli bölümlerinin yazımında sorumluluk almak, Yazım ve dilbilgisi dışında bilimsel olarak gönderilmeden önce makaleyi gözden geçirme. TEMIZ A: Araştırma ve/veya makalenin hipotezini veya fikrini oluşturan, Sonuçlara ulaşmak için planlama/metodoloji belirleme Sonuçların mantıksal olarak Yorumlanması ve sonuçlandıııması, Çalıșma için gerekli literatür taramasında sorumluluk almak, Çalıșmanın bütününün veya önemli bölümlerinin yazımında sorumluluk almak, Yazım ve dilbilgisi dıșında bilimsel olarak gönderilmeden önce makaleyi gözden geçirme. EZER S: Araștırma ve/veya makalenin hipotezini veya fikrini oluşturan, Sonuçlara ulașmak için planlama/metodoloji belirleme, Araştırma/çalısmanın sorumluluğunu üstlenmek, ilerlemenin seyrini denetlemek, Sonuçların mantıksal olarak Yorumlanması ve sonuçlandırılması, Çalıșma için gerekli literatür taramasında sorumluluk almak, Calıșmanın bütününün veya önemli bölümlerinin yazımında sorumluluk almak, Yazım ve dilbilgisi dıșında bilimsel olarak gönderilmeden önce makaleyi gözden geçirme. iNÇE E: Araștırma ve/veya makalenin hipotezini veya fikrini olușturan, Sonuçlara ulașmak için planlama/metodoloji belirleme, Sonuçların mantıksal olarak Yorumlanması ve sonuçlandırıması, Yazım ve dilbilgisi dışında bilimsel olarak gönderilmeden önce makaleyi gözden geçirme. DEMiR Ş: Araştırma ve/veya makalenin hipotezini veya fikrini oluşturan, Sonuçlara ulaşmak için planlama/metodoloji belirleme, Sonuçların mantıksal olarak Yorumlanması ve sonuçlandırılması, Yazım ve dilbilgisi dıșında bilimsel olarak gönderilmeden önce makaleyi gözden geçirme. HASBAY B: Araştırma ve/veya makalenin hipotezini veya fikrini oluşturan, Sonuçlara ulaşmak için planlama/ metodoloji belirleme, ilerlemenin seyrini denetlemek, Sonuçların mantıksal olarak Yorumlanması ve sonuçlandırılması,Yazım ve dilbilgisi dışında bilimsel olarak gönderilmeden önce makaleyi gözden geçirme.

Atıf yazım şekli / How to cite : Gezer HÖ, Temiz A, Ezer S, İnce E, Demir Ş ve Hasbay B. Çocuklarda Akut Apandisit; Ultrasonografinin Tanısal Güvenilirliğinin
\end{abstract} Değerlendirilmesi. Türkiye Çocuk Hast Derg 2021;15:123-128.
Yazışma Adresi / Correspondence Address:

Hasan Özkan GEZER

Başkent Üniversitesi Tıp Fakültesi,

Çocuk Cerrahisi Anabilim Dalı, Adana, Türkiye

E-posta: hozkangezer@yahoo.com.tr
Geliş tarihi / Received : 14.01.2020 Kabul tarihi / Accepted : 28.02.2020 Elektronik yayın tarihi : 10.03.2020 Online published

DOI: 10.12956/tchd.674851 


\section{ABSTRACT}

Objective: Acute appendicitis is one of the most common causes of abdominal pain in patients referring to the emergency department, and appendectomy is one of the most commonly used emergency medical surgeries worldwide. If it is not diagnosed on time, it may cause morbidity with important complications such as perforation. Correct diagnosis can be made in most cases. However, compared with adults, diagnosis is more difficult in children who are anxious, restless and painful and who have not enough communication skills for expressing their complaints well. The aim of this study was to evaluate the accuracy of abdominal ultrasonography (USG) in the diagnosis of acute appendicitis in pediatric patients.

Material and Methods: Patients between 1-18 years who were operated between 2012and 2020 with the estimated diagnosis of appendicitis in pediatric surgery clinic, and who have had USG examination before surgery, were included in the study. Demographic indicators, USG findings at the time of diagnosis, surgical data and pathology reports were evaluated retrospectively.

Results: A total of 500 patients, 203 (40\%) girls and 297 (60\%) boys, were evaluated. The mean age of the patients was $10.1 \pm 3.9$ years. According to preoperative USG data; $30 \%$ of patients had normal appendicitis and $70 \%$ had acute appendicitis (10\% of them perforated). In terms of pathological diagnosis, normal appendix tissue (negative appendectomy) was found in $8 \%$ of the operated patients. The sensitivity, specificity and accuracy of ultrasound were $71.96 \%, 48.78 \%$ and $70.06 \%$, respectively. Positive and negative predictive values were $94.03 \%$ and $13.42 \%$, respectively.

Conclusion: According to the results, it is considered that USG is an easy and inexpensive method in the diagnosis of acute appendicitis in children, but its reliability is still controversial. Diagnostic accuracy was higher in patients where ultrasonography reported as in favor of appendicitis compared to those reported against appendicitis. We consider that the clinical findings of the patients should be reviewed more carefully and if necessary further examination should be performed in patients who do not have appendicitis in the ultrasonographic evaluation.

Key Words: Appendicitis, Children, Sensitivity, Specifity, Ultrasonography

\section{Giriş}

Apendiks çekumun arka yüzünün iç yan tarafında ve ileoçekal valvin $2 \mathrm{~cm}$ altında başlar ve uzunluğu $5-15 \mathrm{~cm}$, çapı 2-5 mm kadardır (1). Normal nüfusun \%65'inde intraperitoneal olarak retroçekal yerleşimlidir. \%30'unda pelvis giriminde veya içinde, $\% 0.5$ 'inde ise ekstraperitoneal olarak çekum veya çıkan kolon arkasındadır (1).

Çocuklarda akut apandisit, acil serviste değerlendirilen karın ağrılarının ve tüm dünyada yapılan acil cerrahi müdahalelerin en sık nedenlerinden biridir (2). Apandisitin oluşmasına intratubüler obstrüksiyon, fekalit birikimi, lenfoid hiperplazi, yabancı cisimler, parazitler ve hatta tümörler neden olabilir. Apandisit çocuklarda yetişkinlere göre daha az görülür, ancak daha sıklıkla komplike olur. Akut apandisitte perforasyon gelişme olasılığı \%20-70 olarak bildirilmiştir (3-5).

Çocuklarda yaygın olarak görülen akut apandisit, morbid bir hastallk olma potansiyeline sahiptir (6). Her yll, Amerika Birleșik Devletleri'nde 80000 çocuk apandisit tanısı almakta olup,14 yaşın altındaki çocuklarda bu hastalığın oluşma insidansı 4/1000 olarak rapor edilmiștir. Pik yaptığı yaş aralığı12-18'dir (6). Akut apandisit hızı ilerleme potansiyeline sahip olduğundan ve perforasyon gibi komplikasyonlarla çok daha karmaşık hale gelebileceğinden, erken ve doğru teşhis son derece önemlidir (7). Zamanında doğru tanı konulamayan hastalarda apendiksin nekrozu veya rüptürü gibi komplikasyonlar sonucu hastada peritonit ve batın içi abse gelişebilir (6). Akut apandisit tanısı çoğunlukla klinik bulgular ve bazı özgül olmayan laboratuvar testlerine dayanılarak konulmaktadır. Semptomları ise klasik semptomlar ile atipik semptomlar arasında geniş bir yelpazede yer alır $(8,9)$. Karın ağrısı, bulantı, kusma, iştahsızlık gibi hastalığa özgü semptomlar hastaların \%50'sinden azında görülür. Dolayısıyla çoğu hasta atipik semptomlar ile başvurur. Çocuklarda apandisitin anatomik farkllığı, fizik muayenede çocuk hastanın uyum sorunları ve hastaların atipik semptomlarla başvurması akut apandisit tanısını koymayı yetişkinlere göre daha güç hale getirmektedir (8). Tanı, ancak \%50-60 hastada görülen ve klasik seyir olarak tariflenen, göbek çevresinden başlayıp sağ iliak fossaya doğru yayılan karın ağrısı ve bunun fizik muayene bulgularına dayanır $(1,3)$.

Görüntüleme teknolojisindeki tüm gelişmelere rağmen, akut apandisiti diğer hastalıklardan ayırt etmek önemli ölçüde hastanın kliniğine ve dikkatli bir fizik muayeneye dayanmaktadır. Bununla birlikte, klinik değerlendirmeye ek olarak yapilan görüntüleme tetkikleri tanının doğruluğunu arttırmada, negatif apendektomi oranını ve hastalığın progresyonunu azaltmada son derece yardımcıdır (7). Bazı çalışmalarda USG, Bilgisayarlı Tomografi (BT) ve manyetik rezonans görüntüleme (MR) tetkikleri tanının doğruluğunu arttırmak için ortak kullanıımış ve hastalığın prognozunu olumlu yönde etkilediği rapor edilmiştir. Ancak, yine de ortak kullanım konusunda henüz kesin kanıtlar yoktur (10). Ek olarak, USG ve BT'nin ameliyat öncesi birlikte rutin kullanımının negatif apendektomi oranını azaltabildiği ve tanının doğruluğunu artırabildiği gösterilmiş olsa da, bu görüşe katılmayan çalışmalar da mevcuttur (11). Neticede çocuklar için halen en dikkate değer nokta, öncelikle düşük riskli tanı yöntemlerinin tercih edilmesi gerektiğidir (10).

Çalışmamızda, kliniğimizde akut apandisit tanısı ile ameliyat edilen hastalarımızın verilerinden yola çıkarak negatif apendektomi oranını azaltmak ve akut apandisitin doğru tanısını koymak açısından, çocuklarda USG'nin duyarlılığı, özgüllüğü ve doğruluğunu değerlendirmeyi hedefledik. 


\section{GEREÇ ve YÖNTEMLER}

Bu kesitsel geriye yönelik çalışma, 2012-2019 yılları arasında Çocuk Cerrahisi Kliniğinde apandisit tanısı ile ameliyat edilen 1-18 yaș arası 500 çocuk üzerinde gerçekleștirildi. Çalıșmaya ameliyat öncesi USG yapılmayan hastalar dahil edilmedi. Çalışma protokolü üniversitesi tıp fakültesi etik kurulu tarafindan onaylandı (KA20/12).

Hastaların tibbi kayitlarından USG raporları, ameliyat bulguları ve patoloji raporlarına ulaşıldı. Pozitif patolojik rapor incelenen dokudaki inflamasyon bulgularına dayandırıldı.

\section{Kriterler:}

1. Özel bir iltihap veya apandisit belirtisi yok (normal apendiks dokusu) ve reaktif foliküler hiperplazi (dokunun uyarıması ve lenfoid agregasyon varlığı).

2. - Erken akut apandisit (Mukozal tabakada polimorfonükleer lökosit (PMN) varlığı),

- Akut apandisit (Kas tabakasında PMN varlığı),

- Akut apandisit ve periappendisit (Seroza tabakasında PMN varlığı),

- Akut süpüratif apandisit (Tüm apendiks duvarında yoğun PMN varlığı)

3. Akut gangrenöz apandisit: Apendiks duvarında nekroz varlığı.

Patoloji raporuna göre 1 normal olarak kabul edildi. 2 akut apandisit, 3 perfore apandisit olarak kabul edildi.

\section{Abdominal Ultrasonografi}

Abdominal ultrasonografi sırasında apandisit tanısına yönelik, Antares 5 (Siemens Medical Solutions, Issaquah, WA) cihazının 9-4 MHz doğrusal dizi transdüseri ile kademeli sıkıștırma tekniği kullanılarak inceleme yapıldı. Apandisit için pozitif USG sonuçları, dış duvar çapı 6 mm'den büyük olan genişlemiş, kompresyona yanıt vermeyen apendiks varlığı, karmașık bir kütlenin varlığı veya bir apandikolitin varlı̆ı olarak tanımlandı. Bu kanıtların olmadığı durumlarda normal olarak rapor edildi. Ultrason verileri, cerrahi bulgular ve patolojik raporları ile korele edildi ve ardından bu veriler veri toplama ve daha ileri analiz için bir kontrol listesine kaydedildi.

\section{İstatistiksel analiz}

Verilerin istatistiksel analizinde SPSS 25.0 paket programı kullanıldı. Kategorik ölçümler sayı ve yüzde olarak, sürekli ölçümlerse ortalama ve standart sapma (gerekli yerlerde ortanca ve minimum - maksimum) olarak özetlendi. Çalıșmada hastaların USG, Cerrahi ve Patoloji arasında sensitivite (duyarllık) ve spesifite (özgüllük), pozitif ve negatif prediktif değerleri hesaplanarak değerlendirildi, yöntemler arasındaki farkllıklar Mc-Nemar testi ile değerlendirildi. Tüm testlerde istatistiksel önem düzeyi 0.05 olarak alındı.

\section{BULGULAR}

Kesitsel tipteki bu çalsşma, akut apandisit tanısı konulan 1-18 yaş arası 500 çocuk üzerinde yapıldı. Bu çocukların 203'ü (\% 40) kız, 297'si (\% 60) erkekti. Hastaların ortalama yaşı $10.1 \pm$ 3.9 yıldı. Hastalar arasında yaș ve cinsiyet açısından anlamlı bir fark olmadığını gösterildi (Tablo I).

USG raporunun sonuçları: Örneklerin 149'unda normal olarak rapor edildi ve bunların ancak 20'sinde patolojik tanı ile uyumlu bulundu. Akut apandisit tanısı için bu oran 238/298, perfore apandisit için ise 44/53'di (Tablo II). USG'nin tanı koymadaki doğruluğu ise Tablo III'te verildi.

\section{TARTIŞMA}

Çoğunlukla çocuklarda apandisit atipik bir klinik seyir gösterdiğinden tanıda yanılmaya veya gecikmeye sebep olabilir. Çalısmalara göre, akut apandisit için negatif laparotomi oranı yaklaşık \% 20-25'dir. Bu oran, çocuk doğurma çağındaki kadınlarda pelvik organ hastalıkları ve gebeliğe bağlı komplikasyonlar nedeniyle \% 35-45'e ulaşmaktadır (10). Çalıșmamızda ise negatif laparotomi oranı \%8 olarak bulundu. Akut apandisit şüphesi olan hastaların tedavisi, hastayı ameliyat etme ya da ameliyat etmeme kararını içerir. Bu nedenle, tanının doğruluğunu artıracak her türlü yardımcı uygulama tedavi öncesi önem kazanmaktadır (10).

Akut apandisit tanısında görüntülemenin amacı, tanı etkinliğini artırmanın yanı sıra hasta için maliyeti ve riski düşürmektir. Bazı çalışmalar, apandisitin klinik semptomlara göre teşhis edilmesinin zor olduğu olgularda, USG' nin tanı koymada çok yardımcı olduğunu ve negatif apendektomi oranını azalttı̆̆ını göstermiştir (12).

Tablo I: Akut apandisit tanısı alan hastaların demografik verilerinin dağllımı.

\begin{tabular}{l|c|c|c|c}
\hline Değişken & Erkek & $\mathbf{K} \mathbf{z}$ & Toplam & p \\
\hline Cinsiyet & $297(\% 60)$ & $203(\% 40)$ & 500 & 0.090 \\
Yaş & $10.1 \pm 3.5$ & $10.1 \pm 3.9$ & $10.1 \pm 3.9$ & 0.184 \\
\hline
\end{tabular}

Tablo II: Akut apandisit nedeniyle ameliyat edilen hastaların USG ve patoloji rapor sonuçlarının dağlımı.

\begin{tabular}{l|c|c|c|c}
\hline & Normal & $\begin{array}{c}\text { Patoloji } \\
\text { Akut } \\
\text { Apandisit }\end{array}$ & $\begin{array}{c}\text { Perfore } \\
\text { Apandisit }\end{array}$ & $\begin{array}{c}\text { Hasta } \\
\text { Sayıs }\end{array}$ \\
\hline USG & & & & \\
$\quad$ Normal & $\mathbf{2 0}$ & 89 & 40 & 149 \\
$\quad$ Akut apandisit & 20 & $\mathbf{2 3 8}$ & 40 & 298 \\
Perfore apandisit & 1 & 8 & $\mathbf{4 4}$ & 53 \\
\hline & 41 & 335 & 124 & 500 \\
\hline
\end{tabular}


Tablo III: Abdominal Ultrasonografi raporlarının istatistiksel sonuçlarının dağıımı.

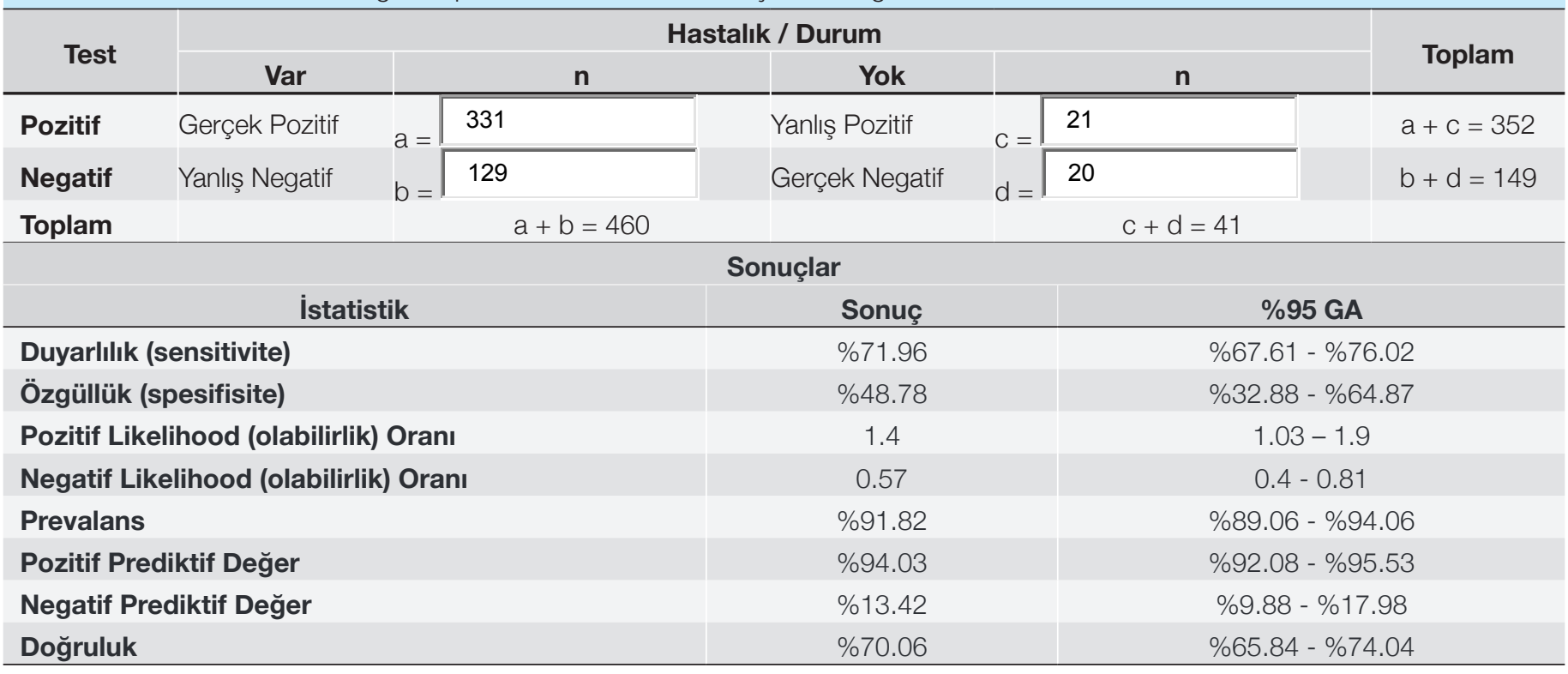

USG, radyasyon riskinin olmaması, kolay uygulanabilir, kolay ulașılabilir ve ucuz olmasının yanı sıra batın içi patolojilerin teşhisinde yüksek hassasiyete sahip bir yöntem olması nedeniyle birçok çalışmada akut apandisit tanısında kullanılıması gereken ilk inceleme yöntemi olarak önerilmektedir. Apandisit işaret eden USG bulguları şunlardır; basmakla komprese olmayan, lümeni genişlemiş, duvarı kalınlaşmış, çapı 6mm'den büyük apendiks, apendiks lümeni içinde apendikolit, apendiks etrafinda sıvı ve apse saptanmasıdır. Şüpheli hastalarda akut apandisiti doğrulamak veya ekarte etmek için USG kullanımı üzerine birçok çalışma yapılmış olmasına rağmen, tetkikin güvenilirliği hala belirsizdir (13-15). USG'nin tanısal doğruluğu büyük oranda yapan kişiye bağlı da olsa, yüksek duyarlııkta düşük riskli bir yardımcı tanı yöntemi olarak yeri göz ardı edilemez(16).

Çalışmamızın sonuçları; USG tanısında gerçek pozitif $n=331$, yanlış pozitif $n=21$, gerçek negatif $n=20$ ve yanlış negatif $n=129$ olduğunu gösterdi. Tanıda USG' nin duyarlıı̆ı \%71.96, özgüllüğü \%48.78 ve doğruluğu \%70.06 olarak tespit edildi. Ayrıca, akut apandisit tanısı için USG' nin pozitif ve negatif prediktif değerleri sırasıyla \% 94.03 ve \% 13.42 olarak hesapland.

Şüpheli olgularda akut apandisiti tanımak veya dışlamak için USG kullanımı üzerine çeşitli çalışmalar yapılmıştır (10). AbuYousef ve ark. (17) çalışmalarında apandisit tanısını koymada USG'nin duyarllığını \% 80, özgüllüğünü de \%95 olarak hesaplamış ve bu çalısmalarına göre patolojik tanısı apandisit olarak rapor edilen her üç vakadan ikisine USG' nin doğru tanı koyduğunu ortaya koymuştur. Bir bașka çalışmada ise USG'nin duyarllığı ve özgüllüğü, sırasıyla \% 96.4 ve \% 67.6 olarak tespit edilmiştir (18). Lessin ve ark. (19) çalışmasında, çocuklarda akut apandisit tanısında USG' nin duyarllığı ve özgüllüğü sırasıyla \% 88 ve \% 96 bulunmuş ve hastaların kliniği ile karar vermeye göre USG nin doğruluk oranı anlamlı derecede yüksek çıkmıştır.
Ramachandran ve ark. (20) tarafindan yapılan bir çalışmada ise USG \% 90 duyarllık, \%96 özgüllük ve \%95 doğrulukta bulunmuştur.

Bunakarşın 3924 hastadayapılan bir çalıșmada USG bulgularının patoloji raporlarıla uyumunun düşük olduğu görülmüştür. Ancak patolojik olarak akut apandisit tespit edilen olguların \% 68.2'sinde USG'de inflamasyon bulguları tespit edilmemiștir. Bu çalışmada USG'nin duyarlıı̆ı \% 21.5 olarak bildirilmiştir (21). Ek olarak, çeşitli çalsşmalara göre, akut apandisit tanısında USG'nin duyarlıı̆̆ı \% 78-96 arasında ve özgüllüğü \% 85-98 arasında bildirilmiştir. Bazı çalışmalar, şüpheli vakalarda USG ile değerlendirmenin literatürde \%11-32 olarak belirtilen negatif apendektomi insidansını \% 7'ye kadar azalttığını ve 6 saatlik cerrahi operasyon gecikmesini \% 2 azalttığını bildirmiştir $(10,22)$. Ancak, sonuçların kalitesi ve doğruluğu büyük ölçüde yapan kişinin becerisine bağlı olduğundan hem çeșitli çalışmaların sonuçlarında büyük farkllıklar görülebilmekte hem de bu durum tetkik için önemli bir dezavantaj olabilmektedir (10).

Son çalışmalara göre, akut apandisiti teşhis etmek için, USG'de en çok görülen ve radyologlar tarafindan kabul edilen bulgu, apendiksin çapının dış duvardan dış duvara ölçülmesidir. Eğer apendiks anterior-posterior çapı 5 mm'den küçükse kesinlikle normaldir ve inflame apendiks çapı 6 mm'den büyüktür (1). Çalışmamızda patolojik tanısı akut apandisit olan hastaların ortalama apandiks çapı $8 \mathrm{~mm}(6-20 \mathrm{~mm})$, perfore apandisitte ise $10 \mathrm{~mm}(6-22 \mathrm{~mm})$ olarak hesaplandı. Perfore apandisit için $9.75 \mathrm{~mm}$ cut-off değer olarak bulundu ( $\mathrm{p}=0.001)$ (duyarllığı \%62, özgüllüğü \%70). Literatürde ayrıca apendikolit ile birlikte sağ alt kadran ağrısı apandisit için pozitif bir bulgu olarak sayılmıştır (1). Çalışmamızda ameliyat sırasında hastaların \%19' unda apendikolit tespit edilmesine rağmen preoperatif olarak bunların ancak \%16'sı USG ile tespit edilebilmiști (duyarlı̆̆ı \%16.1, özgüllüğü \%95.6). 
Periapendiküler, Douglas'ta ve Morison poşunda serbest SIVI apandisiti destekleyen USG bulgularıdır (1). Çalışmamızda ise bu açıdan USG'nin duyarlı̆ı̆ı ve özgüllüğü sırasıyla \%53.4 ve \%65.8 olarak tespit edildi. Bu düşük duyarlıığın nedeni olarak ameliyat sırasında tespit edilen reaksiyonel mayinin de ameliyat raporlarına yazılmış olması olduğunu düşünüyoruz.

Ek olarak, akut apandisitte, apendiks duvarında çevresel görüşlü kan akışı görülmesi tanının doğruluğu açısından güçlü bir gösterge olarak düșünülmüștür. Ancak bu yöntemin kullanımında her zaman sınılamalar ve problemler olduğu belirtilmektedir (23).

Rüptüre apandisitin USG'nin doğruluğunu azalttığını söyleyen çalışmalar, bunu perfore apandisitte apandiksin dekomprese olmasına ve bu nedenle apandikse ait kitle görünümünün ultrasonografik olarak tanımlanamamasına bağlamıșlardır $(22,24)$. Ancak bu konudaki veriler çok fazla değildir. Quillin ve ark.(22) sağ alt kadranda veya cul-de-sac'da sıvı bulunmasının ve apandikolitin perfore apandisite özgü olmadığını ileri sürmektedirler. Buna ek olarak serbest sıvı varlığının perfore apandisitte daha sık görüldügünü ancak akut ile perfore apandisit arasında bu açıdan istatistiksel olarak anlamlı bir fark olmadığı belirtilmektedir (22). Biz çalışmamızda perfore apandisit nedeniyle ameliyat edilen hastalarda USG'nin duyarlılı̆ını \%52.38, özgüllüğünü \%95.24, pozitif prediktif değerini \%97.78, negatif prediktif değerini \%33.33 olarak tespit ettik. Özellikle apendiks vizualize edilemiyor ve batın içerisinde yaygın yoğun içerikli sıvı görülüyorsa perfore apandisit için güçlü bir veri olduğunu düşünüyoruz. Apendektomi apsesi gibi apandisit komplikasyonlarının saptanmasında ultrasonun doğruluğu, komplikasyonsuz apandisitten daha fazladır (10).

USG' nin sınıllayıcıları olarak karın ağrısı çeken ve henüz iletişim becerileri iyi gelişmeyen çocuğun işleme uyumsuzluğu, obez hastaların karnının sağ alt kadranında gaz dolu bağırsakların varlığı, yüksek çözünürlüklü transdüserlerin olmaması, komplike olmamış küçük apendiks gibi yapıların gözlemlenmesi olarak sayılabilir (18). Bu nedenle gelişmiş ülkelerde dahi \% 15-30 negatif apendektomi bildirilmektedir (3).

Literatürde akut apandisiti tespit etmede USG'nin duyarllı̆̆ı \% 55-96 ve özgüllüğü \% 85-98 arasında bildirilmekte ve deneyimli kişilerin ellerinde bu oranların artabileceği rapor edilmektedir (\% 75-95 duyarllık, \% 87-96 doğruluk) (25). Ayrıca son çalışmalarda renkli doppler USG'nin akut apandisiti tespit etmek için güvenilir bir yöntem olduğu düșünülmüș ve rutin USG'ye Renkli Doppler USG'nin eklenmesinin tanısal doğruluğu artıracağı bildirilmiștir (26). Ancak tanıdaki duyarlıı̆ı \% 87-93 oranında raporlanmıştır (25). Tüm bu bulgular ışığında, deneyimli personel ve uygun cihazlar ile yapıldığında, USG'nin hastalarda akut apandisit tanısı için kullanılabilecek iyi bir görüntüleme yöntemi olduğu düşünülmektedir (10).

Sonuç olarak, USG akut apandisit şüphesi olan çocuklarda yardımcı tetkik olarak kullanılabilir. Tanının doğruluğu yapan kişiye bağlı olsa da, yüksek hassasiyetli düşük riskli bir tanı yöntemidir. Ayrıca, bu yöntemi kullanmanın negatif apendektomi oranını azaltmada etkili bir rol oynayabileceği görülmektedir. USG'nin farklı zamanlarda farklı radyologlar tarafından yapılmış olması, çalışmamızda kısıtlayıcı bir neden olarak düşünülebilir. Yine de çalıșmamızda negatif prediktif değer oldukça düşük bulunduğundan, USG bulgularının tanısal değerinin olmadığı hastalarda, kliniğin daha detaylı değerlendirilmesi ve gerekirse ileri tetkik yapılması gerektiğini düşünüyoruz.

\section{KAYNAKLAR}

1. Behzatolu B, Hatipoğlu E, Bayramoğlu S, Yılmaz G, Yirik G, Cimilli T. Akut Apandisit Tanısında Ultrasonografi ve Bilgisayarlı Tomografi Bulgularının Karşılaştıııması. Med J Bakirkoy 2006;2:22-4.

2. Yıldız T, Illçe Z, Turan G, Bozdağ Z, Elmas B. Parasites in the Etiology of Pediatric Appendicitis. Turkiye Parazitol Derg 2015;39:190-3.

3. Öztaş T, Dursun A, Söğütçü N, Bilici S. Unusual Histopathological Findings in Appendectomy Specimens Obtained from 1683 Pediatric Patients with Suspected Acute Appendicitis. Indian Journal of Surgery 2019:81-344 doi: 10.1007/s12262-018-18144.

4. Okoro KU, De La Espriella MG, Grider DJ, Baffoe-Bonnie AW. Tuberculous Enteritis Presenting as Acute Appendicitis and Perirectal Abscess. Case Rep Med 2018;2018:6068258.

5. KIlıc ŞS. Çocuklarda apandisit. Med J SDU / SDÜ Tıp Fak Derg 2015:Çocuk Özel Sayısı:12-16.

6. Almaramhy $\mathrm{HH}$. Acute appendicitis in young children less than 5 years: review article. Ital J Pediatr 2017;43:15.

7. Kaiser S, Jorulf H, Söderman E, Frenckner B. Impact of radiologic imaging on the surgical decisionmaking process in suspected appendicitis in children. Acad Radiol 2004;11:971-9.

8. Bachur RG, Dayan PS, Bajaj L, Macias CG, Mittal MK, Stevenson $M D$, et al. The effect of abdominal pain duration on the accuracy of diagnostic imaging for pediatric appendicitis. Ann Emerg Med 2012;60:582-590.e3.

9. Erikci VS. Management of Pediatric Appendicitis. Current Issues in the Diagnostics and Treatment of Acute Appendicitis: Intech Open 2018

10. Pedram A, Asadian F, Roshan N. Diagnostic Accuracy of Abdominal Ultrasonography in pediatric Acute Appendicitis. Bull Emerg Trauma 2019;7:278-83.

11. Sauvain MO, Slankamenac K, Muller MK, Wildi S, Metzger U, Schmid W, et al. Delaying surgery to perform CT scans for suspected appendicitis decreases the rate of negative appendectomies without increasing the rate of perforation nor postoperative complications. Langenbecks Arch Surg 2016;401:643-9.

12. Alvarado A. Clinical Approach in the Diagnosis of Acute Appendicitis. Current Issues in the Diagnostics and Treatment of Acute Appendicitis: IntechOpen; 2018. DOI: 10.5772/intechopen.75530.

13. Nielsen JW, Boomer L, Kurtovic K, Lee E, Kupzyk K, Mallory R, et al. Reducing computed tomography scans for appendicitis by introduction of a standardized and validated ultrasonography report template. J Pediatr Surg 2015;50:144-8.

14. Sauvain MO, Slankamenac K, Muller MK, Wildi S, Metzger U, Schmid W, et al. Delaying surgery to perform CT scans for suspected appendicitis decreases the rate of negative appendectomies 
without increasing the rate of perforation nor postoperative complications. Langenbecks Arch Surg 2016;401:643-9.

15. Boonstra PA, van Veen RN, Stockmann HB. Less negative appendectomies due to imaging in patients with suspected appendicitis. Surg Endosc 2015;29:2365-70.

16. Marzouni HZ, Davachi B, Rezazadeh M, Milani MS, Matinfard S. Diagnostic Value of Hepatic Vein Ultrasound in Early Detection of Liver Cirrhosis. GMJ 2018;7:1140.

17. Abu-Yousef MM, Bleicher JJ, Maher JW, Urdaneta LF, Franken Jr E, Metcalf A. High-resolution sonography of acute appendicitis. AJR Am J Roentgenol 1987;149:53-8.

18. Chen SC, Wang HP, Hsu HY, Huang PM, Lin FY. Accuracy of ED sonography in the diagnosis of acute appendicitis. Am J Emerg Med 2000;18:449-52.

19. Lessin MS, Chan M, Catallozzi M, Gilchrist MF, Richards C, Manera $\mathrm{L}$, et al. Selective use of ultrasonography for acute appendicitis in children. Am J Surg 1999;177:193-6.

20. Ramachandran P, Sivit CJ, Newman KD, Schwartz MZ. Ultrasonography as an adjunct in the diagnosis of acute appendicitis: a 4-year experience. J Pediatr Surg 1996;31:164-7.
21. Marusch F, Allecke K, Gastinger I. Value of ultrasound in diagnosis of appendicitis. Results of the East German Multicenter Study. East German Working Group "Outcome Assessment and Quality Assurance in Surgery" of the CAQ of the GermanSociety of Surgery. Zentralbl Chir 1998;123:29-31.

22. Günșar C, Karaca I, Ceylan H, Etensel B, Șencan A, Çetin GG, ve ark. Çocukluk çağı akut ve perfore apandisitlerinde ultrasonografik bulguların tanı değerleri. Akademik Gastroenteroloji Dergisi 2004;3: 88-92.

23. Hahn HB, Hoepner FU, Kalle T, Macdonald EB, Prantl F, Spitzer $\mathrm{IM}$, et al. Sonography of acute appendicitis in children: 7 years experience. Pediatr Radiol 1998;28:147-51.

24. Townsend CM, Beauchamp RD, Evers BM, Mattox KL. Sabiston textbook of surgery 20 th Edition. E-book: Elsevier Health Sciences; 2012

25. Heller MT, Hattoum A. Imaging of acute right lower quadrant abdominal pain: differential diagnoses beyond appendicitis. EmergRadiol 2012;19:61-73. 